\title{
Analisis Fitur Warna dan Tekstur untuk Metode Deteksi Jalan
}

\author{
Adhi Prahara, Ahmad Azhari \\ Teknik Informatika, Universitas Ahmad Dahlan \\ JI. Prof. Dr. Soepomo, S.H., Umbulharjo, Yogyakarta 55164, (0274) 563515 \\ e-mail: adhi.prahara@tif.uad.ac.id, ahmad.azhari@tif.uad.ac.id
}

\begin{abstract}
Road detection is used to identify road area on image or video. The challenges in road detection are variety of road color and road texture, and illumination problem. Therefore, appropriate features are needed to deal with these problems. In this research, analysis of color and texture features is done to detect road area. A collection of 50 samples of road image is taken to be extracted its color features in three different color spaces such as RGB (Red-Green-Blue), HSV (Hue-Saturation-Value), and CIE $L^{*} a^{*} b^{*}$ and to be extracted its texture features using GLCM (Gray Level Co-occurrence Matrix). These features are analyzed to determine the color and texture threshold. The result of road detection method using color and texture threshold obtained from the previous features analysis shows $90.54 \%$ accuracy from 150 test images.
\end{abstract}

Keywords: road detection; color space; color feature; texture feature; GLCM

\section{Abstrak}

Deteksi jalan digunakan untuk mengidentifikasi area jalan pada citra atau frame video. Tantangan dalam mendeteksi jalan diantaranya warna dan tekstur jalan yang beragam serta masalah pencahayaan. Oleh karena itu diperlukan fitur yang sesuai untuk menghadapi permasalahan tersebut. Pada penelitian ini dilakukan analisis fitur warna dan tekstur untuk mendeteksi jalan. Kumpulan 50 sampel jalan diambil untuk diekstrak fitur warna di tiga ruang warna yang berbeda yaitu RGB (Red-Green-Blue), HSV (Hue-Saturation-Value), dan CIE L*a*b* serta diekstrak fitur teksturnya dengan GLCM (Gray Level Co-occurrence Matrix). Fitur-fitur tersebut kemudian dianalisis untuk didapatkan fitur dengan variasi yang rendah dari semua sampel jalan yang digunakan untuk menentukan threshold warna maupun tekstur. Hasil pengujian metode deteksi jalan dari 150 citra uji jalan menggunakan batasan fitur hasil analisis menunjukkan akurasi 90,54\%.

Kata Kunci: deteksi jalan; ruang warna; fitur warna; fitur tekstur; GLCM

\section{Pendahuluan}

Deteksi jalan pada sistem pengawasan lalu lintas secara otomatis digunakan untuk mengidentifikasi area jalan pada masukan citra atau frame video yang diambil dari kamera pengawas lalu lintas. Pada sistem pengawasan lalu lintas secara otomatis, biasanya metode deteksi jalan digunakan untuk melokalisasi area deteksi untuk kendaraan atau pejalan kaki. Hal ini bertujuan untuk meminimalkan kesalahan deteksi dengan cara mengarahkan sistem untuk mendeteksi kemungkinan posisi kendaraan atau pejalan kaki berada.

Beberapa tantangan dalam mendeteksi jalan diantaranya adalah warna dan tekstur jalan yang beragam serta masalah pencahayaan karena obyek jalan berada di luar ruangan. Warna dan tekstur jalan tergantung dari material yang digunakan untuk membangun jalan sedangkan pencahayaan tergantung dari kondisi cuaca, pencahayaan matahari atau lampu jalan. Jalanan seringkali tertutup bayangan dari pohon atau gedung disekitar jalan yang membuat warnanya menjadi lebih gelap daripada bagian jalan yang terkena cahaya langsung.

Dari beberapa penelitian yang telah dilakukan untuk mendeteksi jalan, deteksi jalan dapat dilakukan menggunakan pembatasan piksel dari fitur warna [1], fitur tekstur [2,3] dan atau 
klasifikasi dengan menggunakan hasil pelatihan fitur-fitur tersebut [4]. He, Wang, dan Zhang mendeteksi jalan dari fitur warna jalan. Tepian jalan digunakan untuk membatasi batas kanan dan kiri jalan sekaligus melokalisasi area jalan dari citra intensitas. Daerah jalan diekstrak dari citra berwarna dan batas tepi jalan diperbaiki dengan perkiraan bentuk jalan. Hasil penelitiannya menunjukkan bahwa metode ini dapat mendeteksi jalan di lalu lintas perkotaan [1].

Zang dan Nagel mengembangkan metode deteksi jalan berbasis tekstur karena tekstur jalan sangat anisotropik dengan orientasi yang kuat. Tekstur ini dideskripsikan menjadi nilai dan arah di bidang orientasi berdasarkan matriks kovarian dari perubahan warna jalan. Metode ini menunjukkan hasil yang baik dalam mendeteksi jalan [2].

Alvarez, Salzmann, dan Barnes mengusulkan metode deteksi jalan dengan metode pembelajaran dari model sampel jalan. Sampel area jalan diambil dari area bagian bawah frame hasil rekaman keadaan lalu lintas di depannya. Model hasil pelatihan digunakan untuk mendeteksi piksel jalan. Hasil penelitian menunjukkan bahwa metode tersebut efektif dalam mendeteksi jalan [4].

Pada penelitian ini, fitur warna dan tekstur akan dianalisis untuk digunakan dalam metode deteksi jalan. Selanjutnya makalah ini dibagi ke dalam beberapa bab yaitu Bab 2 berisi tentang metode penelitian analisis fitur warna dan tekstur untuk metode deteksi jalan, Bab 3 berisi tentang hasil dan pembahasan serta Bab 4 berisi kesimpulan dari penelitian ini.

\section{Metode Penelitian}

Pada penelitian ini, fitur warna dan fitur tekstur pada area jalan dianalisis dan digunakan pada metode deteksi jalan untuk mendeteksi jalan. Fitur warna diekstrak dari tiga ruang warna yaitu RGB (Red-Green-Blue), HSV (Hue-Saturation-Value), dan CIE (Commission International de l'Clairage) $\mathrm{L}^{*} \mathrm{a}^{*} \mathrm{~b}^{*}$. Fitur warna yang digunakan yaitu rata-rata, varian, skewness, dan kurtosis. Fitur tekstur diekstrak dari ruang warna grayscale untuk dihitung matriks konkurensinya dengan GLCM (Gray Level Co-occurrence Matrix). Dari GLCM kemudian dihitung nilai kontras, korelasi, energi, dan homogenitas. Fitur yang diekstrak kemudian dianalisis untuk mendapatkan fitur dengan nilai variasi yang rendah sebagai penentuan ambang batas dari fitur warna dan tekstur jalan.

\subsection{Ruang Warna}

Warna merupakan cara dari sistem penglihatan manusia dalam mengukur bagian spektrum gelombang elektromagnetik [5] yaitu diantara rentang 400nm - 770nm [6] sedangkan ruang warna merupakan notasi dari manusia dalam menentukan warna [5]. Ruang warna dirancang sesuai persepsi penglihatan manusia terhadap warna.

\section{Ruang warna RGB}

Pada sensor optik, terdapat tiga sensor yang beroperasi di zona panjang gelombang yang berbeda yaitu pendek (biru), menengah (hijau), dan panjang (merah). Misalnya $r(\lambda), g(\lambda)$, dan $b(\lambda)$ adalah respons dari sensor terhadap ketiga zona tersebut, $E(\lambda)$ adalah kecepatan dari sumber cahaya yang cahayanya memantul dari obyek di $X$ dan diproyeksikan ke bidang citra di $x, \rho(\lambda)$ adalah spektrum pantulan dari permukaan di $X$, maka intensitas $\mathrm{R}, \mathrm{G}$, dan $\mathrm{B}$ dari sensor di koordinat $x$ pada bidang citra dihitung dengan persamaan (1) [7].

$$
\begin{aligned}
& R=\int_{\lambda} E(\lambda) \rho(\lambda) r(\lambda) d \lambda \\
& G=\int_{\lambda} E(\lambda) \rho(\lambda) g(\lambda) d \lambda \\
& B=\int_{\lambda} E(\lambda) \rho(\lambda) b(\lambda) d \lambda
\end{aligned}
$$

Ketiga intensitas merah, hijau dan biru kemudian disebut dengan warna primer. Ruang warna yang merepresentasikan warna ini disebut dengan ruang warna RGB. Pada citra RGB 24bit, masing-masing rentang intensitas pada setiap komponen di ruang warna RGB adalah 0-255. 


\section{Ruang warna grayscale}

Ruang warna grayscale merupakan representasi kecerahan warna dari ruang warna RGB. Berdasarkan International Telecommunication Union Rec. ITU-R BT.601-7 [8], konversi dari ruang warna $\mathrm{RGB}$ ke ruang warna grayscale $(\mathrm{Y})$ ditunjukkan pada persamaan (2).

$$
Y=0.299 R+0.587 G+0.114 B
$$

\section{Ruang warna CIE L*a*b*}

Ruang warna CIE L*a*b* merupakan ruang warna standar dari CIE (Commission International de l'Clairage) dan didasarkan dari persepsi manusia terhadap warna. CIE L*a* $\mathrm{b}^{*}$ terdiri dari komponen $L^{*}$ yang mewakili kecerahan warna, dan dua komponen kromatis, $a^{*}$ dan $b^{*}$. Komponen kromatis $a^{*}$ mengindikasikan posisi warna berada di sumbu merah-hijau dan komponen kromatis $b^{*}$ mengindikasikan posisi warna berada sumbu biru-kuning. Konversi dari ruang warna RGB membutuhkan konversi ke ruang warna CIE XYZ terlebih dahulu dengan menggunakan persamaan (3) kemudian ke ruang warna CIE $L^{*} a^{*} b^{*}$ yang ditunjukkan pada persamaan (4) [6].

$$
\begin{gathered}
{\left[\begin{array}{l}
X \\
Y \\
Z
\end{array}\right]=\left[\begin{array}{lll}
0.412453 & 0.357580 & 0.180423 \\
0.212671 & 0.715160 & 0.072169 \\
0.019334 & 0.119193 & 0.950227
\end{array}\right]\left[\begin{array}{l}
R \\
G \\
B
\end{array}\right]} \\
X=\frac{X}{X_{n}}, X_{n}=0.950456 \\
Z=\frac{Z}{Z_{n}}, Z_{n}=1.088754 \\
L=\left\{\begin{array}{c}
116 Y^{\frac{1}{3}}-16, Y>0.008856 \\
903.3 Y, \quad Y \leq 0.008856
\end{array}\right. \\
a=500(f(X)-f(Y))+\delta \\
b=200(f(Y)-f(Z))+\delta \\
t^{\frac{1}{3}}, \quad t>0.008856 \\
\quad t)=\left\{\begin{array}{c}
0.137931, t \leq 0.008856 \\
7.787 t+0
\end{array}\right. \\
\delta=\left\{\begin{array}{cc}
128, & 8 \text { bit } \\
0, & 32 \text { bit }
\end{array}\right.
\end{gathered}
$$

\section{Ruang warna HSV}

Ruang warna HSV mempunyai tiga komponen yaitu hue $(\mathrm{H})$, saturation (S), dan value (V). Hue mewakili atribut dari persepsi manusia terhadap warna. Berdasarkan CIE (Commission International de l'Clairage), warna hitam, putih, dan abu-abu tidak termasuk di dalam rentang warna hue. Oleh karena itu, hue disebut juga warna kromatis. Saturation mewakili tingkat kewarnaan dari warna sedangkan value mewakili kecerahan dari warna. Konversi warna dari ruang warna RGB ke ruang warna HSV ditunjukkan pada persamaan (5) [6].

$$
\begin{gathered}
V=\max (R, G, B) \\
S=\left\{\begin{array}{cc}
\frac{V-\min (R, G, B)}{V}, & \begin{array}{c}
V \neq 0 \\
\text { otherwise }
\end{array}
\end{array}\right.
\end{gathered}
$$


Jurnal IImu Teknik Elektro Komputer dan Informatika (JITEKI)

Vol. 2, No. 2, Desember 2016

$$
H=\left\{\begin{array}{c}
\frac{60(G-B)}{V-\min (R, G, B)}, \quad V=R \\
120+\frac{60(B-R)}{V-\min (R, G, B)}, \quad V=G \\
240+\frac{60(R-G)}{V-\min (R, G, B)}, V=B \\
H=H+360, H<0
\end{array}\right.
$$

\subsection{Fitur Momen Warna}

Momen warna mengukur karakteristik dari distribusi warna. Fitur momen warna invarian terhadap rotasi dan skala. Momen warna yang digunakan biasanya pada orde rendah seperti rata-rata, deviasi standar, skewness dan kurtosis. Fitur rata-rata mengukur nilai rata-rata dari distribusi warna, deviasi standar mengukur nilai variasi dari distribusi warna, skewness mengukur tingkat asimetris dari distribusi warna, dan kurtosis mengukur seberapa datar atau tinggi distribusi warna terhadap distribusi normal. Bila rata-rata $(\bar{x})$, deviasi standar $(\sigma)$, skewness $(S)$, kurtosis $(k)$, jumlah data adalah $N$ dan $x_{i}$ adalah data piksel ke-i maka momen warna secara berurutan dapat dihitung dengan persamaan (6-9).

$$
\begin{gathered}
\text { rata }- \text { rata }=\bar{x}=\frac{1}{N} \sum_{i=0}^{N} x_{i} \\
\text { deviasi standar }=\sigma=\sqrt{\frac{1}{(N-1)} \sum_{i=0}^{N}\left(x_{i}-\bar{x}\right)^{2}} \\
\text { skewness }=s=\sum_{i=0}^{N}\left(x_{i}-\bar{x}\right)^{3} /\left(N \sigma^{3}\right) \\
\text { kurtosis }=k=\sum_{i=0}^{N}\left(x_{i}-\bar{x}\right)^{4} /\left(N \sigma^{4}\right)
\end{gathered}
$$

\subsection{Fitur Tekstur}

Tekstur dari citra dapat direpresentasikan dengan GLCM (Gray Level Co-occurrence Matrix). GLCM menghitung seberapa sering pasangan piksel dengan nilai tertentu dan relasi spasial muncul di dalam citra. Sudut orientasi dari relasi spasial yaitu $0^{\circ}, 45^{\circ}, 90^{\circ}$, dan $135^{\circ}$. Setelah GLCM dibuat, fitur tekstur dapat diesktrak dengan menghitung statistik dari matriks tersebut. Dari 14 pengukuran fitur tekstur yang dapat diekstrak dari GLCM [9], pada penelitian ini digunakan empat fitur tekstur yaitu kontras, korelasi, energi, dan homogenitas yang ditunjukkan pada persamaan (10-13).

$$
\begin{gathered}
\text { contrast }=\sum_{i, j}|i-j|^{2} p(i, j) \\
\text { correlation }=\sum_{i, j} \frac{(i-\mu i)(j-\mu j) p(i, j)}{\sigma_{i} \sigma_{j}} \\
\text { energy }=\sum_{i, j} p(i, j)^{2} \\
\text { homogeneity }=\sum_{i, j} \frac{p(i, j)}{1+|i-j|}
\end{gathered}
$$


dimana $p(i, j)$ adalah nilai pada koordinat GLCM (i, j), $\mu i=\sum_{i, j} i\left(p_{i, j}\right)$ dan $\mu j=\sum_{i, j} j\left(p_{i, j}\right)$ adalah rata-rata dari GLCM $i$ dan $j, \sigma_{i}=\sqrt{\sum_{i, j} p_{i, j}\left(i-\mu_{i}\right)^{2}}$ dan $\sigma_{j}=\sqrt{\sum_{i, j} p_{i, j}\left(j-\mu_{j}\right)^{2}}$ adalah deviasi standar dari GLCM $i$ dan $j$.

\subsection{Evaluasi}

Evaluasi dari kesesuaian fitur yang dipilih dari hasil analisis fitur warna dan fitur tekstur dilakukan dengan cara menerapkan fitur tersebut ke dalam metode deteksi jalan untuk dihitung performa kinerjanya. Bila TP (True Positive) menunjukkan hasil area deteksi jalan yang sama dengan area jalan sebenarnya, TN (True Negative) menunjukkan hasil deteksi latar belakang yang sama dengan latar belakang sebenarnya, FP (False Positive) menunjukkan hasil area deteksi jalan yang sebenarnya merupakan latar belakang, dan FN (False Negative) menunjukkan hasil deteksi latar belakang yang sebenarnya adalah area jalan maka akurasi, sensitivitas, spesifisitas, dan presisi dapat dihitung dengan persamaan (14-17) secara berurutan.

$$
\begin{gathered}
\text { akurasi }=\frac{T P+T N}{(T P+T N+F P+F N)} \times 100 \% \\
\text { sensitivitas }=\frac{T P}{(T P+F N)} \times 100 \% \\
\text { spesifisitas }=\frac{T N}{(T N+F N)} \times 100 \% \\
\text { presisi }=\frac{T P}{(T P+F P)} \times 100 \%
\end{gathered}
$$

\section{Hasil dan Pembahasan}

Penelitian tentang analisis fitur warna dan tekstur untuk metode deteksi jalan menggunakan 50 sampel citra jalan dan 150 citra uji yang diambil dari basis data KITTI [10]. Citra sampel jalan digunakan untuk analisis fitur warna dan fitur tekstur sedangkan citra uji digunakan untuk pengujian metode deteksi jalan menggunakan batasan fitur dari hasil analisis sebelumnya.

\subsection{Analisis Warna Jalan}

Citra sampel jalan diekstrak fiturnya menggunakan momen warna yaitu rata-rata, deviasi standar, skewness dan kurtosis. Hasil dari ekstraksi fitur warna kemudian dibandingkan untuk dicari fitur warna yang mempunyai deviasi standar kecil yang mewakili similaritas dari setiap sampel citra jalan. Perbandingan fitur rata-rata, deviasi standar, skewness, dan kurtosis disetiap sampel citra jalan untuk ruang warna RGB ditunjukkan pada Gambar 1a - Gambar 1d, HSV pada Gambar 2a - Gambar 2d, dan CIE L*a*b* pada Gambar 3a - Gambar 3d secara berurutan.

Dari Gambar 1 dan Gambar 2, terlihat bahwa fitur momen warna disetiap komponen warna pada ruang warna RGB dan HSV kurang mewakili similaritas dari citra jalan. Hal ini ditunjukkan dari simpangan fitur yang lebar di seluruh sampel citra jalan. Sedangkan dari Gambar 3, pada komponen warna $a^{*}$ dan $b^{*}$ dari ruang warna $\operatorname{CIE~} L^{*} a^{*} b^{*}$ ditunjukkan similaritas dari citra jalan dengan simpangan fitur yang kecil di seluruh sampel citra jalan. Nilai rata-rata dan deviasi standar dari masing-masing fitur warna di keseluruhan 50 sampel citra jalan ditunjukkan pada Tabel 1 untuk setiap komponen ruang warna secara berurutan.

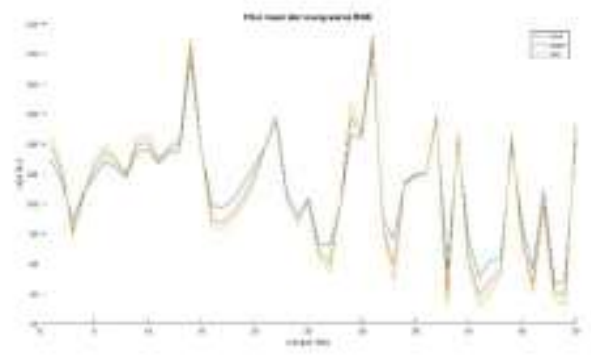

(a) fitur rata-rata

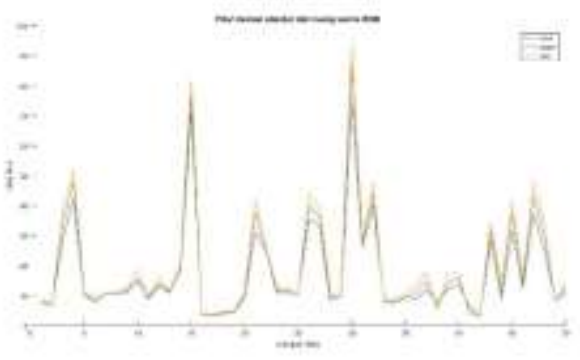

(b) fitur deviasi standar 
Jurnal IImu Teknik Elektro Komputer dan Informatika (JITEKI)

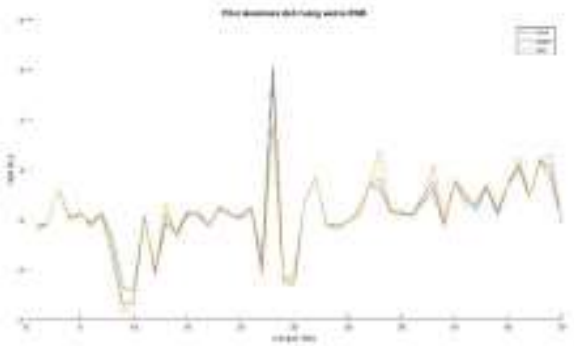

(c) fitur skewness

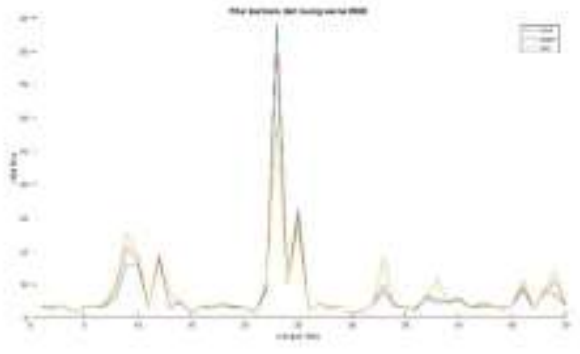

(d) fitur kurtosis

Gambar 1. Distribusi fitur warna jalan di ruang warna RGB

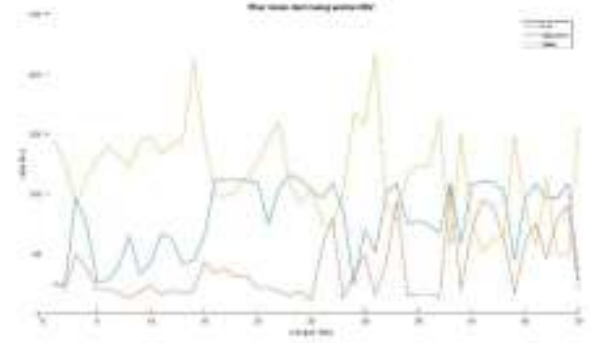

(a) fitur rata-rata

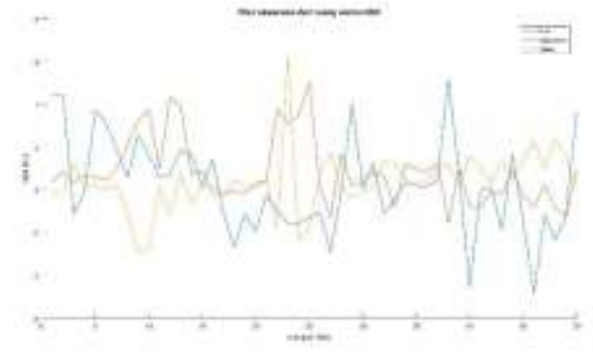

(c) fitur skewness

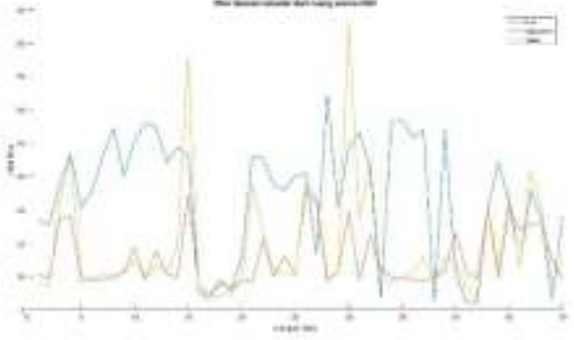

(b) fitur deviasi standar

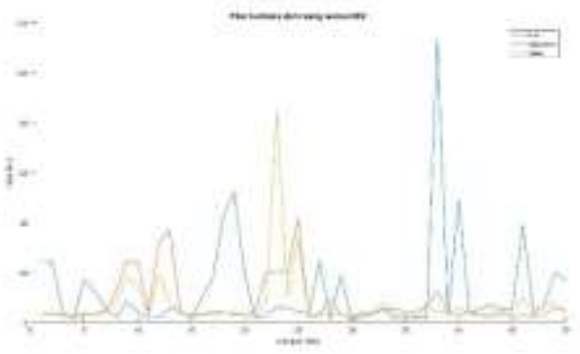

(d) fitur kurtosis

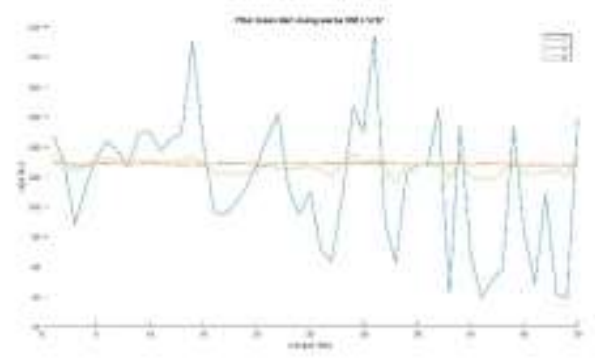

(a) fitur rata-rata

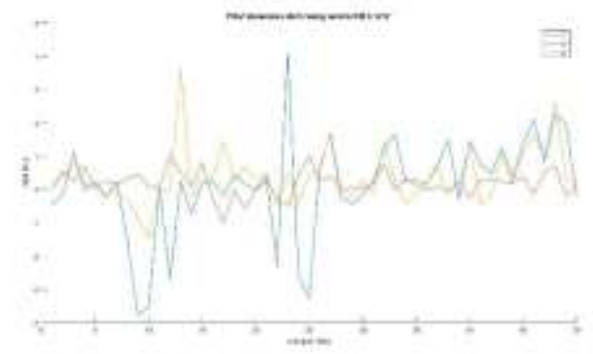

(c) fitur skewness

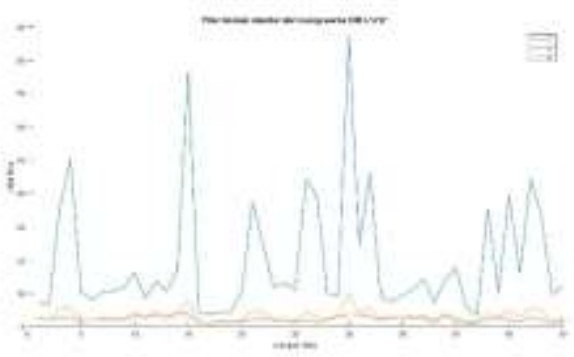

(b) fitur deviasi standar

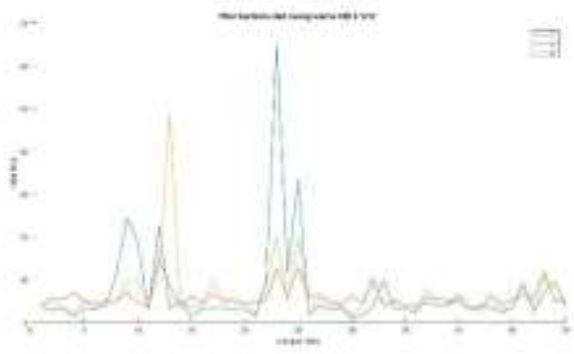

(d) fitur kurtosis

Gambar 3. Distribusi fitur warna jalan di ruang warna $\mathrm{CIE} \mathrm{L*a*b*}$ 
Jurnal IImu Teknik Elektro Komputer dan Informatika (JITEKI)

Vol. 2, No. 2, Desember 2016

Tabel 1. Rata-rata dan simpangan setiap fitur di setiap komponen warna dari 50 sampel

\begin{tabular}{crrrr}
\hline $\begin{array}{c}\text { Komponen } \\
\text { warna }\end{array}$ & Rata-rata & Deviasi standar & Skewness & \multicolumn{1}{c}{ Kurtosis } \\
\hline $\mathrm{R}$ & $110,97 \pm 35,25$ & $17,43 \pm 15,51$ & $0,27 \pm 1,43$ & $7,03 \pm 12,90$ \\
\hline $\mathrm{G}$ & $108,88 \pm 40,88$ & $18,99 \pm 17,86$ & $0,24 \pm 1,50$ & $7,20 \pm 11,91$ \\
\hline $\mathrm{B}$ & $108,13 \pm 44,63$ & $20,78 \pm 19,27$ & $0,24 \pm 1,50$ & $7,37 \pm 9,48$ \\
\hline $\mathrm{H}$ & $78,09 \pm 30,77$ & $33,87 \pm 18,39$ & $0,21 \pm 2,19$ & $12,62 \pm 19,17$ \\
\hline $\mathrm{S}$ & $37,35 \pm 26,73$ & $15,09 \pm 8,70$ & $0,85 \pm 1,53$ & $8,02 \pm 9,44$ \\
\hline $\mathrm{V}$ & $116,16 \pm 39,13$ & $18,89 \pm 17,30$ & $0,36 \pm 1,41$ & $7,19 \pm 12,46$ \\
\hline $\mathrm{L}^{*}$ & $115,43 \pm 42,90$ & $19,58 \pm 18,26$ & $0,11 \pm 1,49$ & $7,13 \pm 10,46$ \\
\hline $\mathrm{a}^{*}$ & $128,38 \pm 0,44$ & $2,23 \pm 0,80$ & $0,17 \pm 0,38$ & $5,89 \pm 2,56$ \\
\hline $\mathrm{b}^{*}$ & $126,40 \pm 4,72$ & $3,30 \pm 1,72$ & $0,38 \pm 0,85$ & $6,60 \pm 7,11$ \\
\hline
\end{tabular}

Dari Tabel 1 terlihat bahwa komponen warna kromatis $a^{*}$ dan $b^{*}$ dari ruang warna CIE $L^{*} a^{*} b^{*}$ mempunyai deviasi standar yang kecil dibandingkan dengan fitur-fitur yang lain. Deviasi standar paling rendah ditunjukkan oleh komponen kromatis $a^{*}$ sehingga untuk ekstraksi fitur warna dipilih ruang warna CIE $L^{*} a^{*} b^{*}$ daripada ruang warna yang lain. Dari ruang warna CIE $L^{*} a^{*} b^{*}$, komponen warna $a^{*}$ dan $b^{*}$ terpisah dari komponen kecerahan $\left(L^{*}\right)$ sehingga fitur ini berguna untuk mengatasi citra jalan yang tertutup bayangan pohon atau terpapar cahaya yang tidak merata. Fitur warna di komponen kecerahan $\left(L^{*}\right)$, menunjukkan citra jalan mempunyai tingkat kecerahan yang tidak terlalu gelap dan tidak terlalu terang yaitu sekitar $50-150$. Dari Tabel 1 dapat dilihat bahwa fitur warna yang sesuai yaitu rata-rata dan deviasi standar dari ruang warna CIE L*a*b* karena mempunyai simpangan yang kecil di semua sampel jalan (diberi tanda dengan warna kuning).

\subsection{Analisa Tekstur Jalan}

Fitur tekstur diesktrak dari citra sampel jalan menggunakan GLCM. GLCM diekstrak pada ruang warna grayscale kemudian dihitung kontras, korelasi, energi, dan homogenitas. Hasil dari ekstraksi fitur tekstur kemudian dibandingkan untuk dicari fitur tekstur yang mempunyai deviasi standar yang kecil untuk mengukur similaritas di setiap sampel citra jalan. Gambar 4 menunjukkan perbandingan fitur tekstur di setiap sampel citra jalan dan Tabel 2 menunjukkan nilai dari rata-rata dan deviasi standar setiap fitur tekstur dari keseluruhan 50 sampel citra jalan. Dari semua fitur tekstur citra jalan, didapatkan fitur korelasi dan homogenitas yang mempunyai nilai varian yang kecil di semua sampel citra jalan (diberi tanda dengan warna kuning). Fitur tekstur yang lain mempunyai nilai varian yang besar sehingga sulit untuk ditentukan similaritasnya.

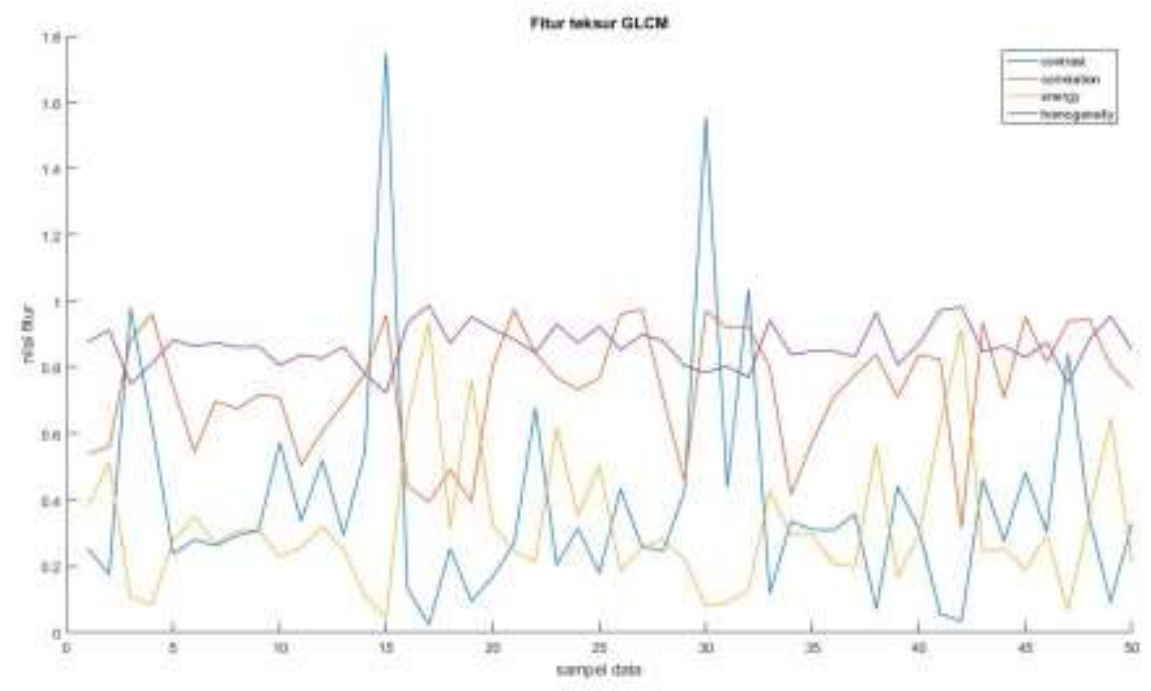

Gambar 4. Fitur tekstur dari GLCM 
Jurnal IImu Teknik Elektro Komputer dan Informatika (JITEKI)

Vol. 2, No. 2, Desember 2016

Tabel 2. Rata-rata dan simpangan dari setiap fitur tekstur dari 50 sampel

\begin{tabular}{lccc} 
KONTRAS & KORELASI & ENERGI & HOMOGENITAS \\
\hline $0,39 \pm 0,34$ & $0,74 \pm 0,18$ & $0,32 \pm 0,21$ & $0,86 \pm 0,06$
\end{tabular}

\subsection{Evaluasi Kinerja}

Hasil analisis fitur warna dan tekstur menghasilkan batasan fitur warna dan tekstur untuk metode deteksi jalan. Fitur yang digunakan untuk metode deteksi jalan dari hasil analisis fitur warna dan tekstur ditunjukkan pada Tabel 3. Batasan simpangan dari setiap fitur menggunakan nilai $2 * \sigma$ dengan $\sigma$ adalah deviasi standar seperti ditunjukkan pada Tabel 3 .

Tabel 3. Batasan fitur hasil analisis fitur warna dan fitur tekstur jalan

\begin{tabular}{lcc}
\hline \multirow{2}{*}{ Rata-Rata } & Komponen Warna & Batasan Fitur \\
\cline { 2 - 3 } & $\mathrm{L}^{*}$ & $115,43 \pm 2^{*} 42,90$ \\
\cline { 2 - 3 } Deviasi Standar & $\mathrm{a}^{*}$ & $128,38 \pm 2^{*} 0,44$ \\
& $\mathrm{~b}^{*}$ & $126,40 \pm 2^{*} 4,72$ \\
\cline { 2 - 3 } & $\mathrm{L}^{*}$ & $19,58 \pm 2^{*} 18,26$ \\
\hline Korelasi & $\mathrm{a}^{*}$ & $2,23 \pm 22^{*} 0,80$ \\
\hline Homogenitas & $\mathrm{b}^{*}$ & $3,30 \pm 2^{*} 1,72$ \\
\hline
\end{tabular}

Performa kinerja dari batasan hasil analisis diuji pada 150 citra uji jalan dari basis data KITTI [10]. Hasil pengujian dilakukan dengan membandingkan piksel jalan yang terdeteksi dengan label ground-truth jalan. Tabel 4 menunjukkan hasil pengujian metode deteksi jalan menggunakan fitur dan batasan dari hasil analisis fitur warna dan tekstur jalan. Dari hasil pengujian di Tabel 4 didapatkan akurasi sebesar $90.54 \%$, hal ini menunjukkan metode mampu mendeteksi piksel jalan dengan baik. Sensitivitas menunjukkan tingkat kepekaan metode dalam memprediksi jalan yakni $87,99 \%$, spesifisitas menunjukkan tingkat kepekaan metode dalam memprediksi latar latar belakang yakni $90,94 \%$ sedangkan presisi menunjukkan tingkat kebenaran metode dalam memprediksi jalan yakni $71,72 \%$. Meskipun mencapai akurasi yang tinggi akan tetapi dari nilai presisi yang sedang mengindikasikan masih terdapat kesalahan dalam deteksi jalan. Kesalahan deteksi terutama diakibatkan dari kemiripan warna dan tekstur obyek dengan obyek jalan.

Tabel 4. Performa hasil pengujian metode deteksi jalan

\begin{tabular}{cccc}
\hline Akurasi (\%) & Sensitivitas (\%) & Spesifisitas (\%) & Presisi (\%) \\
\hline 90,54 & 87,99 & 90,94 & 71,72 \\
\hline
\end{tabular}

Gambar 5 menunjukkan contoh citra hasil deteksi dengan metode yang diusulkan. Dari Gambar 5, warna magenta menunjukkan piksel jalan yang terdeteksi, warna biru merupakan piksel jalan dari label ground-truth, warna hijau merupakan piksel bukan jalan, dan warna merah adalah kesalahan deteksi. Terlihat dari Gambar 5 bahwa kesalahan deteksi disebabkan oleh area yang mirip dengan jalan seperti trotoar, pembatas jalan, atau kendaraan yang berada diatas jalan.
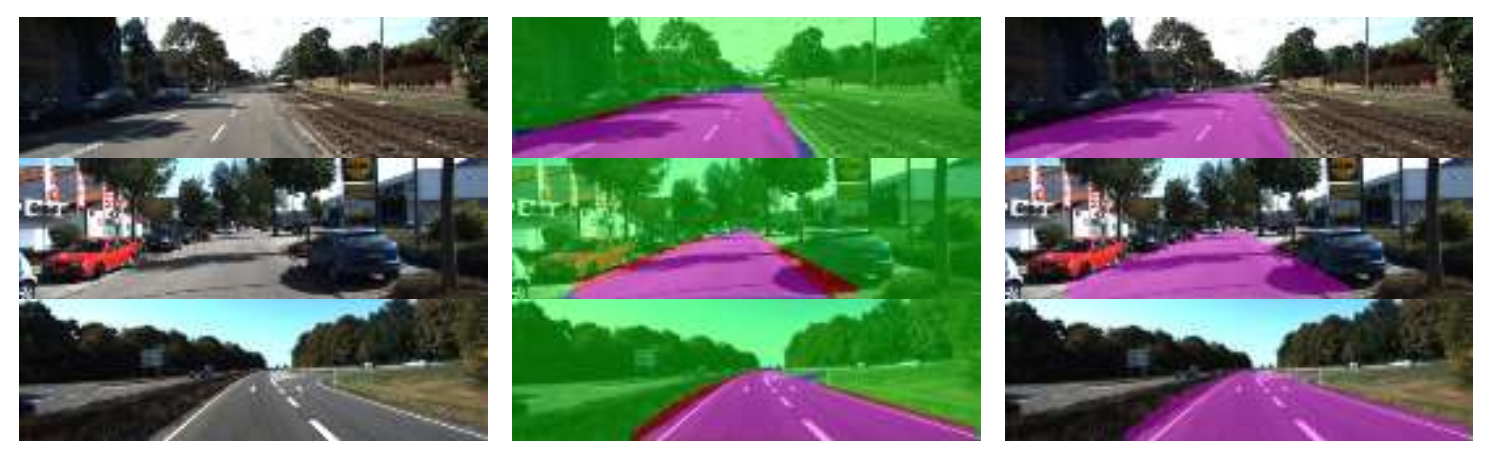

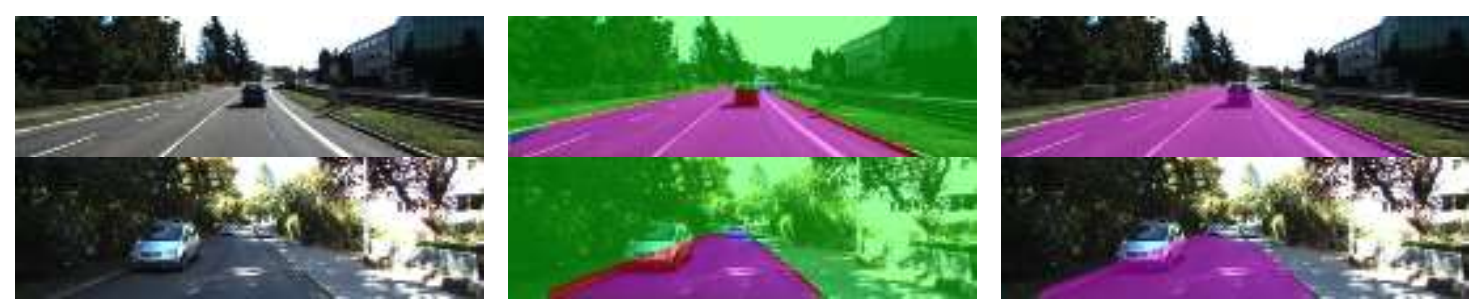

Gambar 5. Hasil pengujian metode deteksi jalan

\section{Kesimpulan}

Penelitian analisis fitur warna dan tekstur dari citra sampel jalan menghasilkan fitur-fitur yang mencerminkan similaritas dari semua sampel citra jalan. Fitur warna yang sesuai dalam mewakili citra jalan yaitu rata-rata dan deviasi standar pada ruang warna $\mathrm{CIE} \mathrm{L}^{*} \mathrm{a}^{*} \mathrm{~b}^{*}$. Fitur tekstur yang sesuai dalam mewakili citra jalan yaitu korelasi dan homogenitas yang diekstrak dari GLCM. Dari hasil pengujian didapatkan hasil yang baik dengan akurasi $90,54 \%$ pada metode deteksi jalan menggunakan batasan dari hasil analisis fitur warna dan tekstur.

\section{Referensi}

[1] He $\mathrm{Y}$, Wang $\mathrm{H}$, Zhang $\mathrm{B}$. Color-based road detection in urban traffic scenes. IEEE Transactions on Intelligent Transportation Systems. 2004; 5(4): 309-318.

[2] Zhang J, Nagel H.H. Texture-based segmentation of road images. In Intelligent Vehicles '94 Symposium, Proceedings of the. 1994; 260-265.

[3] Hui G, Jilin L, Yaya L. Road Extracting Based on Texture Analysis. In 16th International Conference on Artificial Reality and Telexistence--Workshops (ICAT'06). 2006; 64-67.

[4] Alvarez J.M, Salzmann M, Barnes N. Learning appearance models for road detection. In 2013 IEEE Intelligent Vehicles Symposium (IV). 2013; 423-429.

[5] Tkalcic M, Tasic J.F. Colour spaces: perceptual, historical and applicational background. In Eurocon. 2003.

[6] Acharya T, Ray A. K. Image Processing - Principles and Applications. Wiley-Interscience. 2005.

[7] Mukhopadhyay J. Image and Video Processing in the Compressed Domain, 1st ed. Chapman \& Hall/CRC. 2011.

[8] ITU-R BT.601-7. ITU Recommendation for Studio encoding parameters of digital television for standard 4:3 and wide-screen 16:9 aspect ratios. 2011. Diakses 12 Desember 2016. Tersedia online di https://www.itu.int/dms_pubrec/itu-r/rec/bt/R-REC-BT.601-7-201103I!!PDF-E.pdf.

[9] Haralick R.M, Shanmugam K, Dinstein I. Textural Features for Image Classification. In IEEE Transactions on Systems, Man and Cybernetics. 1973; SMC-3: 610-621.

[10] Database KITTI untuk evaluasi jalan. Diakses 12 Desember 2016. Tersedia online di http://www.cvlibs.net/datasets/kitti/eval_road.php. 